\title{
Enhanced Photocatalytic Properties of Pure and Cr-Modified ZnS Powders Synthesized by Precipitation Method
}

\author{
Bedour A. Mahammed, Luma M. Ahmed* \\ Chemistry Department, College of Science, Karbala University, Karbala, Iraq \\ Email: *lumamajeed2013@gmail.com
}

How to cite this paper: Mahammed, B.A. and Ahmed, L.M. (2017) Enhanced Photocatalytic Properties of Pure and Cr-Modified ZnS Powders Synthesized by Precipitation Method. Journal of Geoscience and Environment Protection, 5, 101-111. https://doi.org/10.4236/gep.2017.510009

Received: September 20, 2017

Accepted: October 22, 2017

Published: October 25, 2017

Copyright $\odot 2017$ by authors and Scientific Research Publishing Inc. This work is licensed under the Creative Commons Attribution International License (CC BY 4.0).

http://creativecommons.org/licenses/by/4.0/

\begin{abstract}
Zinc sulfide photocatalysts doped with chromium (1:1)\% were synthesized via precipitation technique. Their characteristics were studied by X-ray diffraction (XRD), AFM and Florescence spectrometer. The photocatalytic reaction was applied under light intensity equal to $1.45 \times 10^{-7}$ Einstein mol-1 to investigate the kinetics and thermodynamic parameters for photo-decolorization of reactive black 5 dye in collide solution of bare and Cr-doped ZnS. The mean crystal size and particle size for bare $\mathrm{ZnS}$ are more than those values for prepared Cr loaded ZnS.
\end{abstract}

\section{Keywords}

Cr-Loaded ZnS, Nanopowders, Reactive Black 5 dye, Azo Dye, Precipitation Method

\section{Introduction}

The reactive dyes are wide consumed in the dye market that due to have a high ability for forming strong covalent bonds with cellulosic fibers via the hydroxyl groups under highly alkaline conditions that leads to a high fastness. Moreover, they have a low cost, highly soluble in water as anionic electrophiles and wide range of color can be given bright colors [1] [2] [3] [4] [5]. There are many types of these dyes that have a general formula structure S-F-T-X, where, $\mathrm{S}$ is solubilizing group like $\mathrm{SO}_{3}$ group, $\mathrm{F}$ is chromophore group like azo or aromatic ring groups, $\mathrm{T}$ is Bridge group such as sulphide, imino, oxide, ethyl \& methyl groups and $\mathrm{X}$ is reactive group such as vinylsulfone and dichlorotriazine that are accountable to bound with cellulosic fibers [5] [6]. In general the chromophore groups in these dyes are determined the kind of the absorbed light area, so, in a 
visible light area the azo bond has absorption, while in the UV light area the aromatic ring has absorption [7]. In the manner, reactive dyes are mainly employed in dying paper and textile industries that release large flows from colored wastewater [8]. Many triers to remove the wastewater in different physical, chemical and biological methods were done such as photocatalytic decolorization [8] [9] [10], adsorption [11] [12] [13], bio-removal [14] [15], photo fenton and fenton-like [16] [17] extraction [18], Coagulation [19] [20] and using dielectric barrier discharge [21].

In this study, the work focused on the optimal conditions for photocatalytic decolorization of reactive black 5 dye with $\mathrm{ZnS}$ powders bare and doped with chromium, perform by precipitation method. This study was described the effects of dose of catalyst, initial $\mathrm{pH}$ of solution, concentration of $\mathrm{K}_{2} \mathrm{~S}_{2} \mathrm{O}_{8}$ and temperature on photoreaction rate.

\section{Practical Part}

\subsection{Chemicals}

In this photocatalytic experiments, all chemicals were used without any further purification. Commercial Zinc sulfide and Thiourea were supplied by Fluka. Other chemicals such as Chromium (III) chloride, Zinc sulphate hepta hydrate and poly ethylene glycol (PEG-4000) were purchased from Merck. $\mathrm{NaOH}$, $\mathrm{NH}_{4} \mathrm{OH}$ and $\mathrm{HCl}$ were supplied by $\mathrm{BDH}$. The textile dye (reactive black 5 dye) was supplied by the Hilla textile factory in Babylon city in Iraq, and the characteristics of it are summarized in Table 1.

\subsection{Preparation of Bare ZnS and (1:1)\% Cr-ZnS Nanopowder}

All prepared solutions were dissolved in distill water then shaking by ultrasonic

Table 1. The main characteristics of reactive black 5 dye [13] [18] [21].

\begin{tabular}{cc}
\hline Ordinary name & $\begin{array}{c}\text { tetrasodium-4-amino-5-hydroxy-3, } 6 \text { (bis(4-(2-(sulfonatooxi) } \\
\text { ethylsulfonyl) phenyl) azo)-naphthalene-2, 7-disulfonate }\end{array}$ \\
Synonyms & $\begin{array}{r}\text { C.I. Reactive Black 5, Reactive Black 5, Remazol Black 5, Reactive Black B, Re- } \\
\text { mazol Black B, Drimaren Black R/K-3B }\end{array}$ \\
Molecular formula & Anionic reactive dye \\
Chemical structure & \\
Chemical class & \\
Molecular weight & \\
$\lambda$ max/nm & \\
Nature & Diazo
\end{tabular}


(FALC) for $10 \mathrm{~min}$ to ensure getting for homogenous solution. The Bare $\mathrm{ZnS}$ and metal loaded $\mathrm{ZnS}$ procedure were modified from procedure in reference [22]. $0.5 \mathrm{M}$ from $\mathrm{ZnSO}_{4}$ was used as starting material. The equal volume from $0.5 \mathrm{M}$ thiourea was taken in a burette and added drop by drop into $\mathrm{ZnSO}_{4}$ solution with vigorous stirring (Labtech-magnetic stirrer) for 25 minutes to get $\mathrm{ZnS}$ solution, and simultaneously $0.05 \mathrm{M}$ from $\mathrm{CrCl}_{3}$ was added to this solution as droping agent using burette for $25 \mathrm{~min}$ to create the $\mathrm{Cr}$ loaded $\mathrm{ZnS}$. This final formed solution was followed by drop wise addition of $1 \%$ of poly ethylene glycol-4000 (PEG-4000) as neutral capping agent solution under vigorous stirring for 1 hour. Afterwards, $0.1 \mathrm{M}$ from ammonia solution was added slowly to solution of metal until the $\mathrm{pH}$ reached to range between 10 and 12, that necessary to generate the metal complex. Finally the metal complex solution was filtrated under vacuum using Büchner's funnel. The precipitate was twice times by using distill water then used absolute ethanol to remove the impurities. The produced precipitate for $\mathrm{ZnS}$ and $\mathrm{Cr} / \mathrm{ZnS}$ were white and grey color as seen as Figure 1, both catalysts were dried overnight by desiccator then dried in oven at less $100^{\circ} \mathrm{C}$ for $2 \mathrm{~h}$ to obtain powder sample.

The suggested chemical equations were investigated from the following equations.

$$
\begin{gathered}
\mathrm{ZnSO}_{4} \cdot 7 \mathrm{H}_{2} \mathrm{O} \rightarrow \mathrm{Zn}^{2+}+\mathrm{SO}_{4}^{2-}+7 \mathrm{H}_{2} \mathrm{O} \\
\mathrm{Zn}^{2+}+\mathrm{SC}\left(\mathrm{NH}_{2}\right)_{2} \rightarrow\left[\mathrm{Zn}\left(\mathrm{SCN}_{2} \mathrm{H}_{4}\right)_{2}\right]^{2+} \\
{\left[\mathrm{Zn}\left(\mathrm{SCN}_{2} \mathrm{H}_{4}\right)_{2}\right]^{2+}+8 \mathrm{O}_{2} \stackrel{\text { PEG-400 }}{\longrightarrow} \mathrm{ZnS} \downarrow+\mathrm{H}_{2} \mathrm{SO}_{4}+2 \mathrm{HNO}_{3}+2 \mathrm{NH}_{2} \mathrm{CO}_{3}}
\end{gathered}
$$

and

$$
\begin{aligned}
& {\left[\mathrm{Zn}\left(\mathrm{SCN}_{2} \mathrm{H}_{4}\right)_{2}\right]^{2+}+\mathrm{CrCl}_{3}+8 \mathrm{O}_{2}} \\
& \stackrel{\mathrm{PEG}-400}{\longrightarrow} \mathrm{Cr} / \mathrm{ZnS} \downarrow+\mathrm{H}_{2} \mathrm{SO}_{4}+2 \mathrm{HNO}_{3}+2 \mathrm{NH}_{2} \mathrm{CO}_{3}+3 \mathrm{Cl}^{-} \\
& \quad \\
& \quad \mathrm{H}_{2} \mathrm{SO}_{4}+2 \mathrm{HNO}_{3}+3 \mathrm{Cl}^{-}+6 \mathrm{NH}_{4} \mathrm{OH} \\
& \rightarrow\left(\mathrm{NH}_{4}\right)_{2} \mathrm{SO}_{4}+2 \mathrm{NH}_{4} \mathrm{NO}_{3}+2 \mathrm{NH}_{4} \mathrm{Cl}+\mathrm{HOCl}+5 \mathrm{H}_{2} \mathrm{O}
\end{aligned}
$$

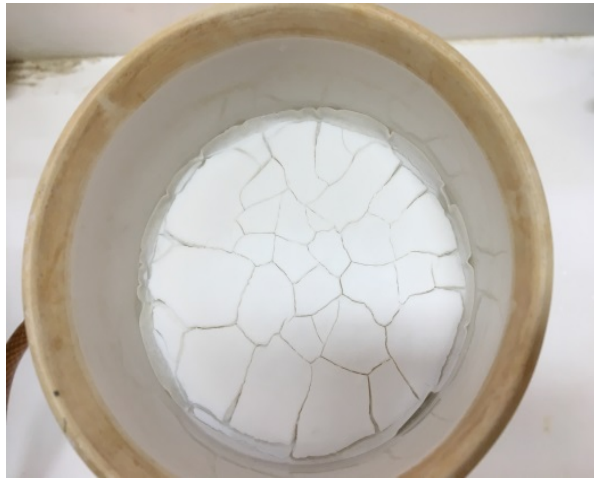

(a)

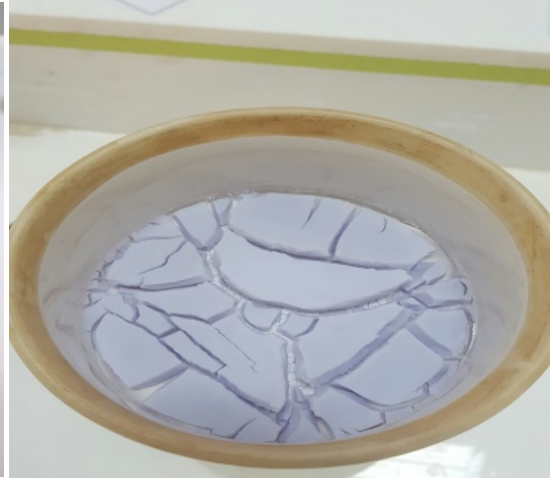

(b)

Figure 1. Images for prepared (a) ZnS nanopowder and (b) Cr loaded $\mathrm{ZnS}$ nanopowder. 


\subsection{Photocatalytic Experiments}

Appropriate grams of photocatalysts ( $\mathrm{ZnS}$ or $\mathrm{Cr}-\mathrm{ZnS}$ ) were added to $100 \mathrm{~mL}$ of $25 \mathrm{ppm}$ from reactive black 5 dye solution. The produced suspension solutions were subjected to UV-A light flux at intensity equal to $1.45 \times 10^{-7}$ Einstein $\mathrm{s}^{-1}$, which calculated by chemical actinometer [23]. At different time intervals, 3.5 $\mathrm{mL}$ was taken out with using syringe and then carried out double separated processes by using centrifuge for $10 \mathrm{~min}$ and $4000 \mathrm{rpm}$. The produced filters were studied by reading the absorption at $595 \mathrm{~nm}$ to find the residue concentration of dye after irradiation.

\section{Results and Discussion}

\subsection{Characterisation of Bare and $\mathrm{Cr}-\mathrm{ZnS}$}

\subsubsection{XRD Analysis}

From XRD spectra in Figure 2, the observed diffraction peaks are broadening that confirmed the crystallites were nanosized [24]. The XRD patterns display the generated of $\mathrm{ZnS}$ nanoparticle, the (111), (200) and (311) planes (JCPDS Card No. 65-9585) were confirmed the $\mathrm{ZnS}$ nanoparticles is prepared at $2 \theta$ equal to $27.76^{\circ}, 32.98^{\circ}$ and $58.6^{\circ}$ respectively [25] [26]. A small and broadening peaks were noticed at around $2 \theta$ values of $13^{\circ}-26^{\circ}$ for both samples, that due to organic moiety PEG that used as capping agent [27] [28]. The diffraction peak of (111) at $27.76^{\circ}$ is slightly shifted to higher angles at $27.88^{\circ}$ for dispersed $\mathrm{Cr}$ ions into the $\mathrm{ZnS}$ matrix. This may be assigned to the small ionic radii of $\mathrm{Cr}^{3+}(0.63$ $\AA)$ that will interact with $\mathrm{Zn}^{2+}(0.74 \AA)$ in $\mathrm{ZnS}$ lattice [29] [30]. Further, after loaded $\mathrm{Cr}$ on $\mathrm{ZnS}$ surface, the (0010) plane at $6.82^{\circ}$ was shifted and become sharp at $8.14^{\circ}$. In (220) plane, the peak was reduced at $41.68^{\circ}$ with loading the chromium ion. From XRD data, the mean crystal size of $\mathrm{ZnS}$ nano and $\mathrm{Cr} / \mathrm{ZnS}$ nano are calculated which depended onto Deby-Scherrer formula [31] and found to equal to $19.986 \mathrm{~nm}$ and $16.21 \mathrm{~nm}$ respectively.

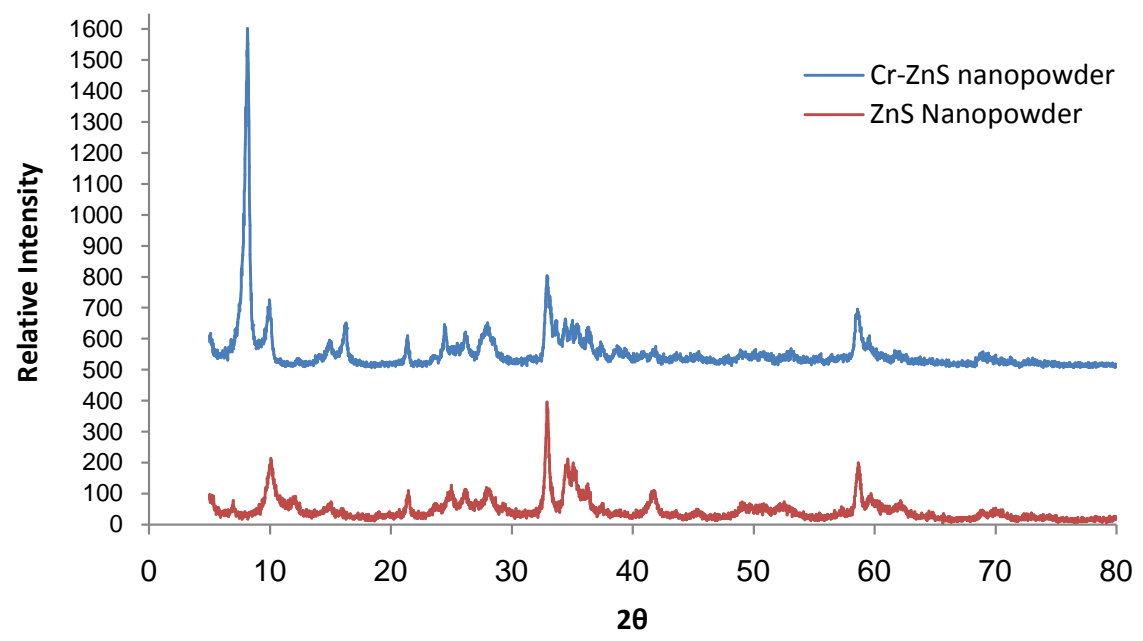

Figure 2. XRD patterns of Bare and $\mathrm{Cr}^{3+}$ loaded on $\mathrm{ZnS}$ nanopowders. 


\subsubsection{AFM Analysis}

The roughness of $\mathrm{ZnS}$ nanopowder is more than that roughness for Cr loaded $\mathrm{ZnS}$ nanopowdr, which appear in Figure 3. The agglomeration is the most dominated in the nanoparticles. The shapes of prepared samples are having semi spherical shape with low agglomeration. This result is in agreement with the reported in reference [32]. The particle sizes for $\mathrm{ZnS}$ nano and $\mathrm{Cr}$ loaded $\mathrm{ZnS}$ nano are measured to be $51.02 \mathrm{~nm}$ and $82.33 \mathrm{~nm}$ respectively.

\subsubsection{Band Gap Energy Measurements}

The band gaps for the above prepared samples were investigated by measuring the fluorescence spectra in Figure 4.

The band gaps (Eg) were calculated employed the following expression in Equation (6) for optical absorption of the above prepared photo-catalysts [33].

$$
B_{g}=\frac{12400}{\lambda}
$$

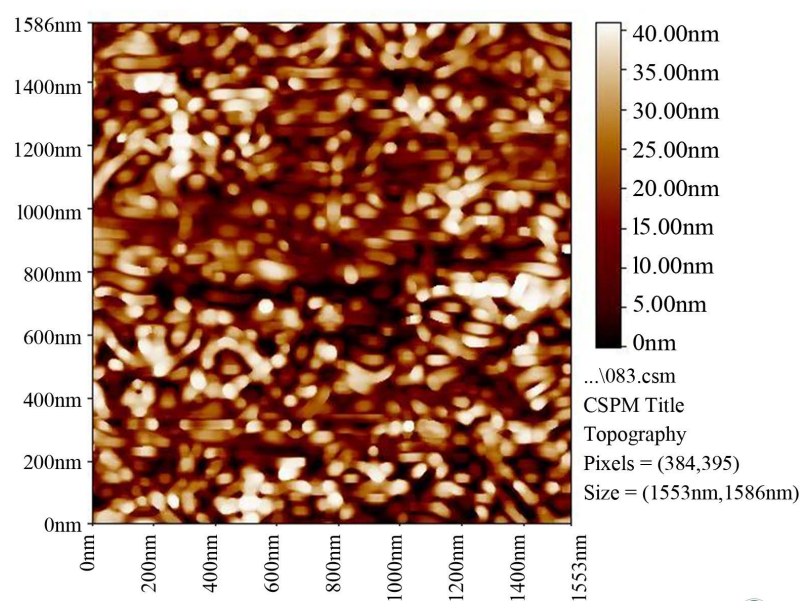

(a)

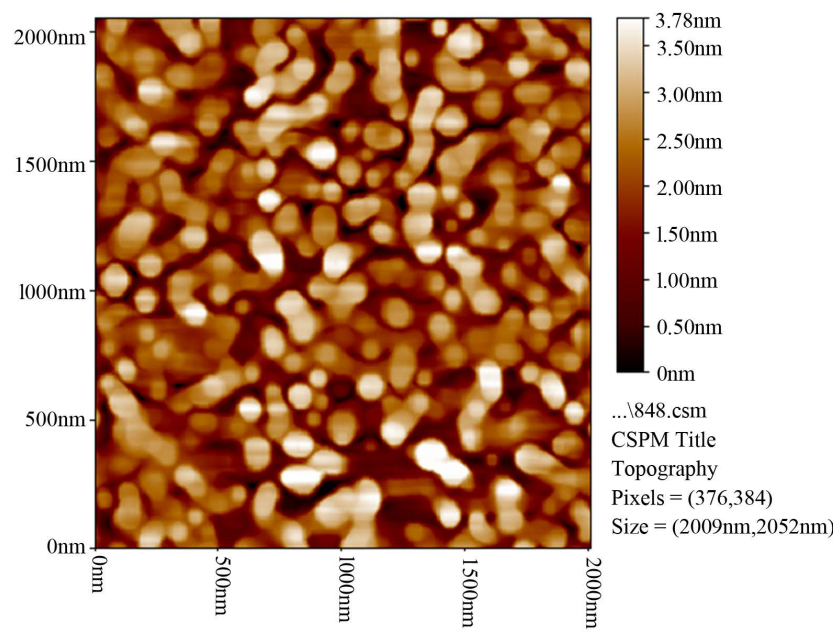

(b)

Figure 3. AFM 2-dimensions Image of (a) bare ZnS nanopowder and (b) Cr Loaded on $\mathrm{ZnS}$ nanopowder. 


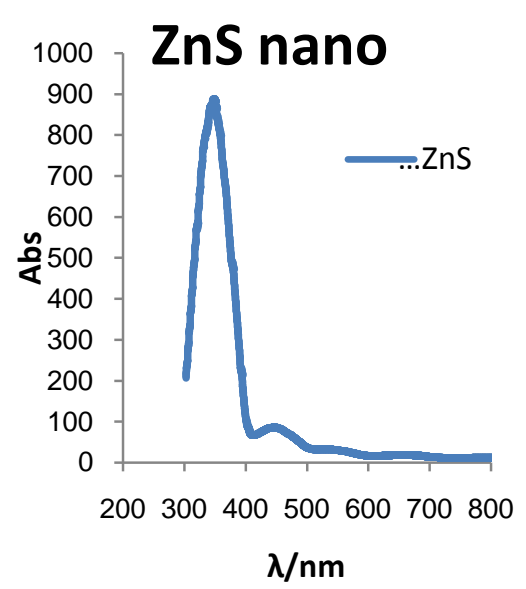

(a)

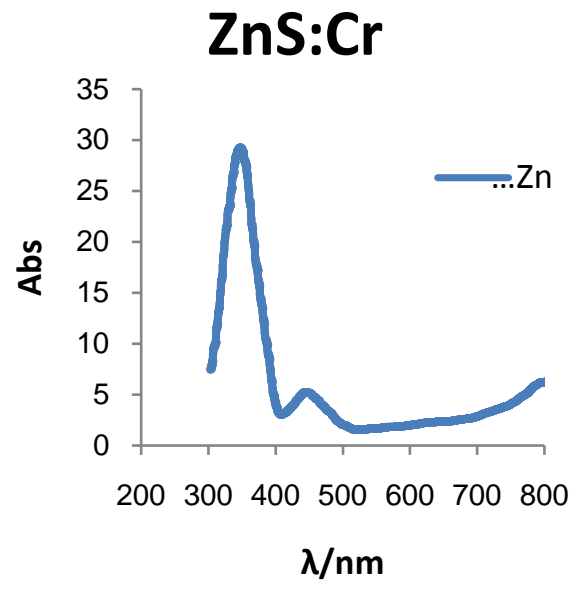

(b)

Figure 4. Fluorescence spectra of (a) bare $\mathrm{ZnS}$ nanopowder and (b) Cr Loaded on $\mathrm{ZnS}$ nanopowder.

The absorption edge for $\mathrm{ZnS}$ nanopowder and $\mathrm{Cr}$ loaded on $\mathrm{ZnS}$ nanopowder were found to be at $348.5 \mathrm{~nm}$ and $347.1 \mathrm{~nm}$ respectively. The bang gaps were found to be $3.558 \mathrm{eV}$ and 3.572 for bare and $\mathrm{Cr}$ loaded $\mathrm{ZnS}$ nanopowder respectively. The slight blue shift in the absorption edge for $\mathrm{Cr}$ loaded on $\mathrm{ZnS}$ nanopowder is related to the calculated bang gap increase when $\mathrm{Cr}$ loaded on $\mathrm{ZnS}$.

\subsection{Effect of the Metal Loading on Photocatalytic Activity}

Figure 5 illustrates, that the metalized process of photo-semiconductor $(\mathrm{ZnS})$ by $\mathrm{Cr}$ leads to increase the rate constant for decolorization of reactive black 5 dye. The rate constant (kapp.) can be calculated by depended on the Langmuir-Hinshelwood kinetic expression to determine Equations (7) and (8) [34]. This reaction is found to be obeyed the pseudo first order.

$$
C_{t}=C_{o} \exp ^{\left(-k_{a p p} \cdot t\right)}
$$

where: $C_{t}$ is a concentration of the reactive black 5 dye at $t$ time of irradiation. $C$ $=$ is an initial concentration of same studied dye at (dark reaction) in 0 min as the time of irradiation. The apparent first order equation can be investigated from Equation (8) [34] [35]:

$$
\ln \left(\frac{C_{o}}{C_{t}}\right)=k_{a p p} \cdot t
$$

The \% Efficiency (\% E) of decolourization for reactive blue 5 dye was calculated using the following relationship that reported in reference [35].

$$
\% \text { Effeciency }=\left(\frac{C_{o}-C_{t}}{C_{o}}\right) \times 100
$$

This result assigns to rise the charge carrier space distance that leads to increase the hole life time and inhibits the recombination process. Moreover, the metal acts as collector of electron by forming a Schottky's barrier [36] [37] [38]. 


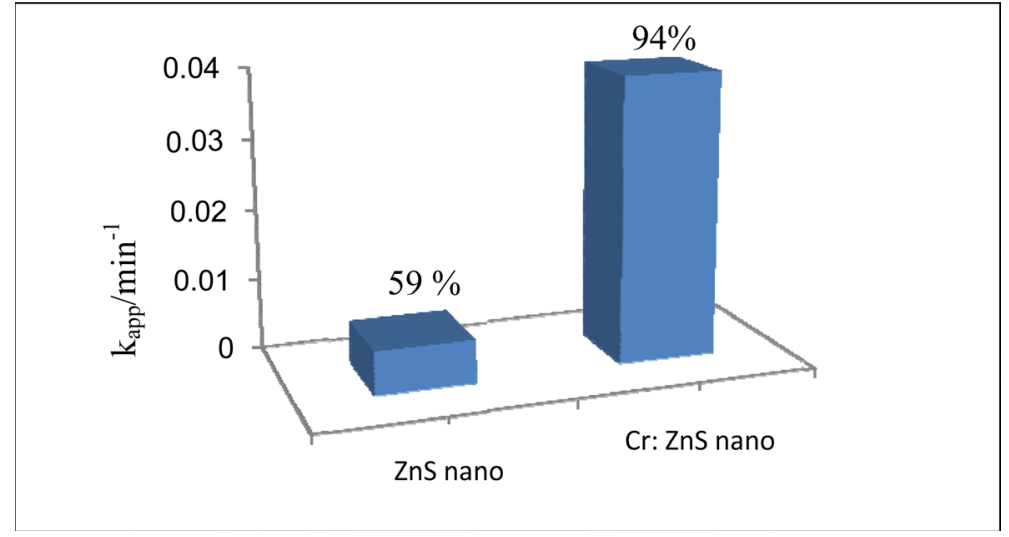

Figure 5. Rate constant of photo reaction as Function of bare $\mathrm{ZnS}$ nano and 1:1 Percentage of Cr loaded on ZnS nano Surface, Used (1 g from catalysts), under Purged environment $\mathrm{O}_{2}$.

The probability for generating this barrier is depended upon the value of work functions fcc (111) for both $\mathrm{Cr}$ and $\mathrm{Zn}$ in $\mathrm{ZnS}$. Hence, the large value for work function of $\mathrm{Cr}$ at fcc (111) 4.5 enhances the interaction between $\mathrm{Cr}$ and $\mathrm{Zn}$ fcc (111) 4.22 in ZnS photocatalyst [39].

\subsection{Suggested Mechanism}

The proposed mechanism for photodecolorization of reactive blue 5 dye (RB5) is occurred in when UV-A light focused on suspension solution of bare ZnS nanopowder or $\mathrm{Cr}$ loaded on $\mathrm{ZnS}$ nanopowder, that perform as system (Dye/sem-iconductor/UV light). The more accepted mechanism is outlined in Scheme 1. In outset, azo bond is oxidative cleavage either C-N or N-N cleavage by attaching the hydroxyl radical that generated via photocatalysis process [40] [41] in presence the prepared photocatalysts. The intermediate I and intermediate II were formed with liberated $\mathrm{N}_{2}$. After that the C-S bond is cleavage in series steps to generate $\mathrm{CO}_{2}$ and $\mathrm{H}_{2} \mathrm{O}$ [41].

\section{Conclusions}

On basis on produced data in this work, the main conclusion can be epitomized:

1) The XRD analysis was evidenced the bare and Cr loaded on $\mathrm{ZnS}$ nanopowder surface. The mean crystal size for bare $\mathrm{ZnS}$ nanopowder is less than that for $\mathrm{Cr}$ loaded $\mathrm{ZnS}$ nanopowder.

2) AFM analysis was indicated the prepared nanopowder shapes are semi-spherical.

3) From the florescence spectra, the calculated band gaps for the bare $\mathrm{ZnS}$ nanopowder were more than that value for $\mathrm{Cr}$ loaded $\mathrm{ZnS}$ nanopowder.

4) The photo-decolorization of reactive blue 5 dye is clearly followed the pseudo first order kinetics by depended on Langmuir-Hinshelwood Kinetic Expression at low concentration.

The nanopowder Cr-ZnS powder has more activity for decolorization of 

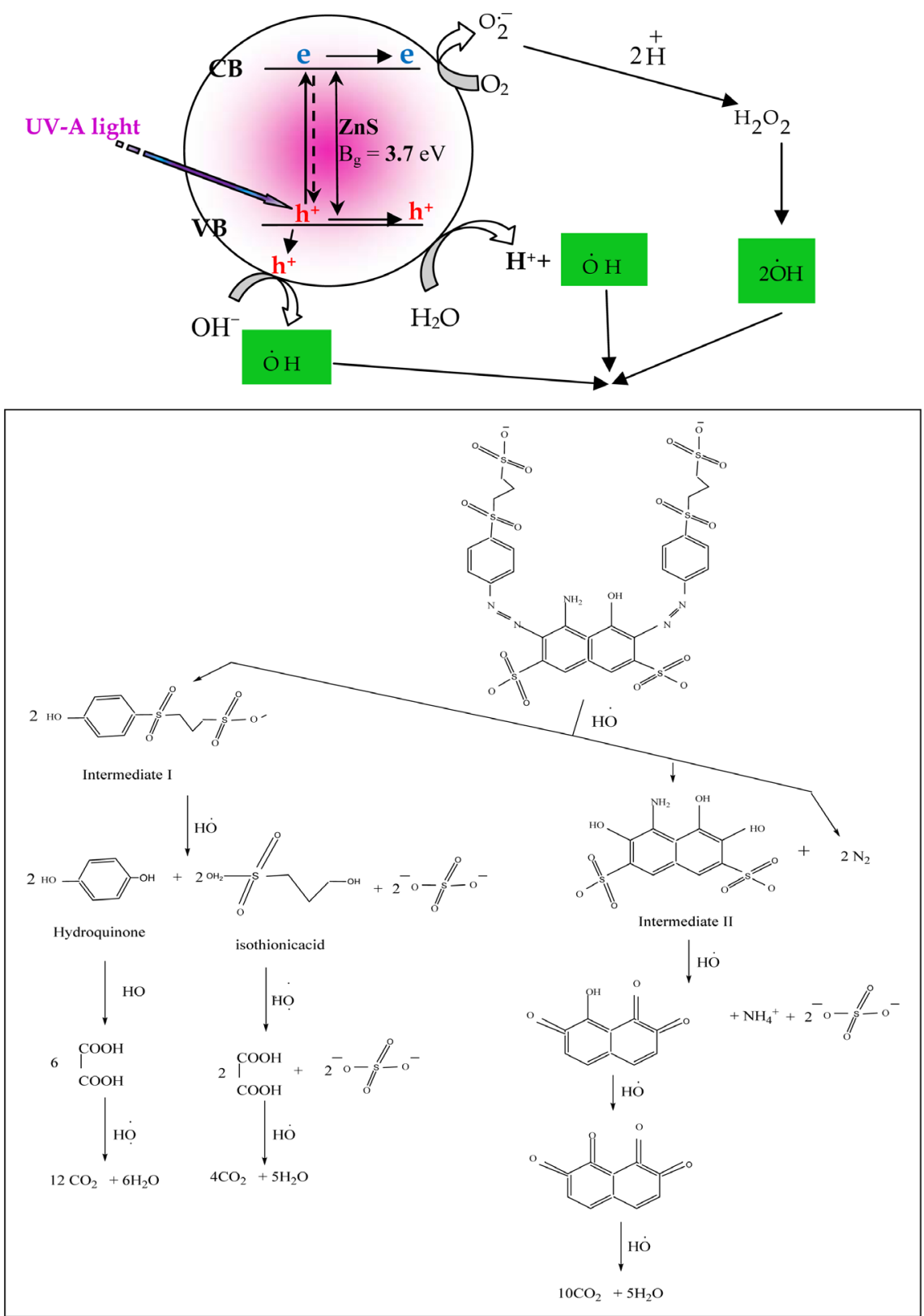

Scheme 1. Schematic diagram for more accepted proposed mechanism as system (Dye/ semiconductor/UV light) (modified from reference [41] [42] [43]).

reactive black 5 dye under ultraviolet light than that for using prepared $\mathrm{ZnS}$ nanopowder to almost $94 \%$ and $59 \%$ in 160 min respectively.

\section{References}

[1] Holme, I. (2000) Coloration of Technical Textiles. Handbook of Technical Textiles, In: Horrocks, A.R. and Anand, S.C., Eds., Woodhead Publishing Ltd, Cambridge, 196-197. https://doi.org/10.1533/9781855738966.187

[2] Lin, S.H. and Lai, C.L. (1999) Catalytic Oxidation of Dye Wastewater by Metal Oxide Catalyst and Granular Activated Carbon. Environment International, 25, 497-504. https://doi.org/10.1016/S0160-4120(99)00015-X 
[3] Alahiane, S., Qourzal, El Ouardi, Abaamrane, S.M.A. and Assabbane A. (2014) Factors Influencing the Photocatalytic Degradation of Reactive Yellow 145 by $\mathrm{TiO}_{2}$-Coated Non-Woven Fibers, American Journal of Analytical Chemistry, 5, 445-454. https://doi.org/10.4236/ajac.2014.58053

[4] Bhatti, I.A., Adeel, S. and Abbas, M. (2011) Effect of Radiation on Textile Dyeing. In: Hauser, P., Ed., Textile Dyeing, ISBN 978-953-307-565-5, InTech, 4.

[5] Chinta, S. and Kumar, S. (2013) Technical Facts and Figures of Reactive Dyes Used in Textiles. International Journal of Engineering and Management Science, 4, 308-312.

[6] Ahmed, A.I. (1995) Texile Dyer and Printer-Reactive Dyes Development-A Review, In: Shenai, A. A., Ed., Technology of Textile Processing, SEVAK Publications, Bombay, 19-24.

[7] Mahvi, A.H., Ghanbarian, M., Nasseri S. and Khairi A. (2009) Mineralization and Discoloration of Textile Wastewater by $\mathrm{TiO}_{2}$ Nanoparticles, Desalination, 239, 309-316. https://doi.org/10.1016/j.desal.2008.04.002

[8] Ahmed, L.M., Tawfeeq, F.T., Abed Al-Ameer, M.H., Al Hussein, K. Abed and Athaab, A.R. (2016) Photo-Degradation of Reactive Yellow 14 Dye (A Textile Dye) Employing $\mathrm{ZnO}$ as Photocatalyst. Journal of Geoscience and Environment Protection, 4, 34-44. https://doi.org/10.4236/gep.2016.411004

[9] Kapoor, S. and Kanwar, A. (2008) Photocatalytic Decolorization of Reactive Black 5 Dye in Aqueous $\mathrm{TiO}_{2} / \mathrm{ZnO}$ Suspension under UV Light. WIT Transactions on Ecology and the Environment, 117, 697-706. https://doi.org/10.2495/SC080651

[10] Ahmed, L.M., Mahdi, Q.M., Mahmoud, F.S., Mahammed, M.J. and Ahmed, N.S. (2017) Kinetic Study for the Decolorization of Dispersive Blue 26 Dye from Suspension Solution of Commercial ZnO. The Fifth Scientific Conference of the College of Science University of Kerbala, Kerbala, 2017, 127-136.

[11] Amin, M.T., Alazba, A.A. and Shafiq, M. (2015) Adsorptive Removal of Reactive Black 5 from Wastewater using Bentonite Clay: Isotherms, Kinetics and Thermodynamics. Sustainability, 7, 15302-15318. https://doi.org/10.3390/su71115302

[12] Samadi, M.T., Zolghadrnasab, H., Godini, Poormohammadi, K.A., Ahmadian, M. and Shanesaz, S. (2015) Kinetic and Adsorption Studies of Reactive Black 5 Removal using Multi-Walled Carbon Nanotubes from Aqueous Solution. Der Pharma Chemica, 7, 267-274.

[13] Yousefi, N., Fatehizadeh, A., Azizi, E., Ahmadian, M., Ahmadi, A., Rajabizadeh, A. and Toolabi, A. (2011) Adsorption of Reactive Black 5 Dye onto Modified Wheat Straw: Isotherm and Kinetics Study. Sacha Journal of Environmental Studies, 1, 81-91.

[14] Zuraida, M.S., Nurhaslina, C.R. and Ku Halim, K.H. (2013) Removal of Synthetic Dyes from Wastewater by Using Bacteria, Lactobacillus delbruckii. International Refereed Journal of Engineering and Science, 2, 1-7.

[15] Mona, S., Kaushik, A. and Kaushik, C.P. (2001) Biosorption of Reactive Dye by Waste Biomass of Nostoc linckia. Ecological Engineering, 3, 589-1594.

[16] Qiu, M., Shou, J., Ren, P. and Jiang, K. (2014) A Comparative Study of the Azo Dye Reactive Black 5 Degradation by $\mathrm{UV} / \mathrm{TiO}_{2}$ and Photo-Fenton Processes. Journal of Chemical and Pharmaceutical Research, 6, 2046-2051.

[17] Hilal, N.M. (2011) Treatment of Reactive Dyeing Wastewater by Different Advanced Oxidation Proceses. Der Chemica Sinica, 2, 262-273.

[18] Mousavi, R. and Nekouei, F. (2011) Cloud Point Extraction of Toxic Reactive Black 
5 Dye from Water Samples Using Triton X-100 as Nonionic Surfactant. E-Journal of Chemistry, 8, 1606-1613. https://doi.org/10.1155/2011/287352

[19] Ashtekar, V.S., Bhandari, V.M., Shirsath, S.R., Sai Chandra, P.L., Jolhe, P.D. and Ghodke, S.A. (2014) Dye Wastewater Treatment-Removal of Reactive Dyes Using Inorganic and Organic Coagulants. Journal of Industrial Pollution Control, 30, 33-42.

[20] Mohamed, R.M., Nanyan, N.M., Abdul Rahman, N.N., Kutty, M.A. and Kassim, A.H. (2014) Colour Removal of Reactive Dye from Textile Industrial Wastewater using Different Types of Coagulants. Asian Journal of Applied Sciences, 2, 650-657.

[21] Dojčinović, B.P., Roglić, G.M., Obradović, B.M., Kuraica, M.M., Tosti, T.B., Marković, M.D. and Manojlović, D.D. (2012) Decolorization of Reactive Black 5 using a Dielectric Barrier Discharge in the Presence of Inorganic Salts. Journal of the Serbian Chemical Society, 77, 535-548. https://doi.org/10.2298/JSC110629179D

[22] Bodo, B., Prakash, D. and Kalita, P.K. (2012) Synthesis and Characterization of ZnS: Mn Nanopartices. International Journal of Applied Physics and Mathematics, 2, 181-183. https://doi.org/10.7763/IJAPM.2012.V2.83

[23] Ahmed, S. (2004) Photo Electrochemical Study of Ferrioxalate Actinometry at a Glassy Carbon Electrode. Journal of Photochemistry and Photobiology A: Chemistry, 161, 151-154.

[24] Rahdar, A. (2013) Study of Different Capping Agents Effect on the Structural and Optical Properties of Mn Doped ZnS Nanostructures. World Applied Programming, 3, 56-60.

[25] Barman, B. and Sarma, K.C. (2010) Synthesis and Optical Properties of ZnS Nanoparticles in PVA Matrix. Optoelectronics and Advanced Materials Rapid Communications, 4, 1594-1597.

[26] Wang, S., Mirov, S.B., Fedorov, V.V. and Camata, R.P. (2004) Synthesis and Spectroscopic Properties of $\mathrm{Cr}$ doped ZnS Crystalline Thin Films. Proceedings of SPIE, 5332, 13-20. https://doi.org/10.1117/12.525899

[27] Shameli, K., Ahmad, M.B., Jazayeri, S.D., Sedaghat, S., Shabanzadeh, P., Jahangirian, H., Mahdavi, M. and Abdollahi, Y. (2012) Synthesis and Characterization of Polyethylene Glycol Mediated Silver Nanoparticles by the Green Method. International Journal of Molecular Sciences, 13, 6639-6650.

https://doi.org/10.3390/ijms13066639

[28] Vasa, D.M., Patel, Nevrekar, H.A., Katz, J., Dalal, N., Roopwani, R., Wildfong, P. and Buckner, I.S. (2013) Use of PEG 400 X-Ray Diffraction Pattern as a Substitute for Amorphous PEG 4000 for Evaluation of Drug Miscibility in Solid Dispersions via PDF Analysis. http://abstracts.aaps.org/Verify/aaps2013/postersubmissions/W5166.pdf

[29] Reddy, D.A., Murali, G., Vijayalakshmi, R.P. and Reddy, B.K. (2011) Room-Temperature Ferromagnetism in EDTA Capped Cr-Doped ZnS Nanoparticles. Applied Physics A, 105, 119-124. https://doi.org/10.1007/s00339-011-6563-1

[30] Bodke, M., Khawal, H., Gawai, U. and Dole, B. (2015) Synthesis and Characterization of Chromium Doped Zinc Sulfide Nanoparticles. Open Access Library Journal, 2, 1-8.

[31] Moore, D. and Reynolds, R. (1997) X-Ray Diffraction and the Identification and Analysis of Clay Minerals. 2nd Edition, Oxford University Press, Oxford, CH 3.

[32] Poojitha, P.T., Madhu, V.K., Rani, S., Chalapthi, U., Kumar, M. and Poornaprakash, B. (2017) Structural, Luminescence and Magnetic Properties of $\mathrm{Cr}^{3+}$ and $\mathrm{Gd}^{3+}$ 
Doped ZnS Nanopowders. Chalcogenide Letters, 14, 11-15.

[33] Cullity, B.D. and Stock, S.R. (2014) Elements of X-Ray Diffraction. 3rd Edition, Pearson Education Limited.

[34] Khezrianjoo, S. and Revanasiddappa, H.D. (2012) Langmuir-Hinshelwood Kinetic Expression for the Photocatalytic Degradation of Metanil Yellow Aqueous Solutions by ZnO Catalyst. Chemical Sciences Journals, 1-7.

[35] Eesa, M.T., Juda, A.M. and Ahmed, L.M. (2016) Thermodynamic and Kinetic Study for Photocatalytic Decolourization of Light Green SF (Yellowish) Dye Using Commercial Bulk Titania and Commercial Nano Titania. International Journal of Science and Research, 5, 1495-1500.

[36] Xu, A.W., Gao, Y. and Liu, H.Q. (2002) The Preparation, Characterization, and Their Photocatalytic Activities of Rare-Earth-Doped $\mathrm{TiO}_{2}$ Nanoparticles. Journal of Catalysis, 207, 151-157. https://doi.org/10.1006/jcat.2002.3539

[37] Ahmed, L.M., Ivanova, I., Hussein, F.H. and Bahnemann, D.W. (2014) Role of Platinum Deposited on $\mathrm{TiO}_{2}$ in Photocatalytic Methanol Oxidation and Dehydrogenation Reactions. International Journal of Photoenergy, 1-9.

https://doi.org/10.1155/2014/503516

[38] Ahmed, L.M., Hussen, F.H. and Mahdi, A.A. (2012) Photocatalytic Dehydrogenation of Aqueous Methanol Solution by Naked and Platinized $\mathrm{TiO}_{2}$ Nanoparticles. Asian Journal of Chemistry, 24, 5564-5568.

[39] Skriver, H. and Rosengaard, N. (1992) Surface Energy and Work Function of Elemental Metals. The American Physical Phenomena, 46, 7157-7168.

[40] Özen, A.S. and Aviyente, V. (2003) Modeling the Oxidative Degradation of Azo Dyes: A Density Functional Theory Study. The Journal of Physical Chemistry A, 107, 4898-4907. https://doi.org/10.1021/jp026287z

[41] Li, G., Park, S. and Rittmann, B.E. (2012) Degradation of Reactive Dyes in a Photocatalytic Circulating-Bed Biofilm Reactor. Biotechnology and Bioengineering, 109, 884-893. https://doi.org/10.1002/bit.24366

[42] Hussein, F.H. (2001) Photochemical Treatments of Textile Industries Wastewater. In: Hauser, P.J., Ed., Advances in Treating Textile Effluent, InTech.

[43] Mashkour, M., Al-Kaim, A., Ahmed, L. and Hussein, F. (2011) Zinc Oxide Assisted Photocatalytic Decolorization of Reactive Red 2 Dye. International Journal of Chemical Sciences, 9, 969-979. 